\title{
The Cloning and Expression of Human Monoclonal Antibodies: Implications for Allergen Immunotherapy
}

\author{
Louisa K. James ${ }^{1}$
}

Published online: 16 January 2016

(C) The Author(s) 2016. This article is published with open access at Springerlink.com

\begin{abstract}
Allergic responses are dependent on the highly specific effector functions of IgE antibodies. Conversely, antibodies that block the activity of $\operatorname{IgE}$ can mediate tolerance to allergen. Technologies that harness the unparalleled specificity of antibody responses have revolutionized the way that we diagnose and treat human disease. This area of research continues to advance at a rapid pace and has had a significant impact on our understanding of allergic disease. This review will present an overview of humoral responses and provide an up-to-date summary of technologies used in the generation of human monoclonal antibodies. The impact that monoclonal antibodies have on allergic disease will be discussed, with a particular focus on allergen immunotherapy, which remains the only form of treatment that can modulate the underlying immune mechanisms and induce long-term clinical tolerance.
\end{abstract}

Keywords Human monoclonal antibodies $\cdot$ Allergen immunotherapy $\cdot \mathbf{B}$ cells $\cdot$ Cloning $\cdot$ Human $\cdot$ Allergy

\section{Introduction}

Allergen immunotherapy (AIT) was introduced over a century ago with the first clinical trial conducted by

This article is part of the Topical Collection on Immunotherapy and Immunomodulators

Louisa K. James

louisa.james@kcl.ac.uk

1 Randall Division of Cell and Molecular Biophysics and MRC and Asthma UK Centre for Allergic Mechanisms of Asthma, King's College London, SE1 1UL London, UK
Noon and Freeman in 1911 [1,2]. The aim of AIT is the induction of clinical tolerance to a sensitizing allergen and has proven highly effective in the treatment of rhinitis, asthma, and venom allergy. Conventional AIT involves the subcutaneous injection of increasing doses of allergen extract over many years. Treatment carries a risk of inducing adverse side effects including systemic anaphylaxis [3]; hence, a major goal of research into AIT has been to improve both safety and efficacy. To this end, alternative routes of allergen administration have or are being successfully adopted (e.g., sublingual, oral, epicutaneous, intralymphatic). Novel vaccine design has led to the development of alternative forms of treatment including peptide immunotherapy, immunotherapy with recombinant allergens or modified allergen extracts, and the use of adjuvants that stimulate innate immune receptors. In addition, the combined use of monoclonal antibody therapy alongside AIT has proven highly successful. Monoclonal antibodies (mAbs) have revolutionized the way we diagnose and treat human disease. Of the mAbs now approved or under review, the overwhelming majority are licensed for use in cancer or autoimmune diseases. Until recently, the only $\mathrm{mAb}$ in clinical use for allergic disease was the anti-IgE antibody Omalizumab (Xolair), which was approved in the USA in 2003 and in Europe in 2005 for patients with asthma. In addition, the anti-IL-5 antibody Mepolizumab has now been approved for use in severe eosinophilic asthma. Rapid technological advances in medicine over recent years provide an opportunity to reassess our understanding of allergic diseases and our approach to AIT. The aims of this review are to assess how advances in monoclonal antibody technology could impact the field of allergy and in particular address some of the challenges of allergen immunotherapy. 


\section{The Breadth of the Humoral Response}

Antibodies are secreted glyco-proteins that recognize and bind to antigen with exquisite specificity through the highly variable fragment antigen binding (Fab) region (Fig. 1). The various effector functions of antibodies are elicited via the fragment crystallizable $(\mathrm{Fc})$ region (Fig. 1), through engagement with $\mathrm{Fc}$ receptors and other components of the immune system.

Human antibodies are encoded within the heavy chain immunoglobulin locus on chromosome $14\left(\mathrm{~V}_{\mathrm{H}}, \mathrm{D}, \mathrm{J}_{\mathrm{H}}\right.$, and $\left.\mathrm{C}_{\mathrm{H}}\right)$, the kappa $(\kappa)$ light chain immunoglobulin locus on chromosome $2(\mathrm{VK}, \mathrm{JK}$ and $\mathrm{CK}$ ), and the lambda $(\lambda)$ light chain locus on chromosome $22(\mathrm{~V} \lambda, \mathrm{J} \lambda$, and $\mathrm{C} \lambda)$. Antibodies are
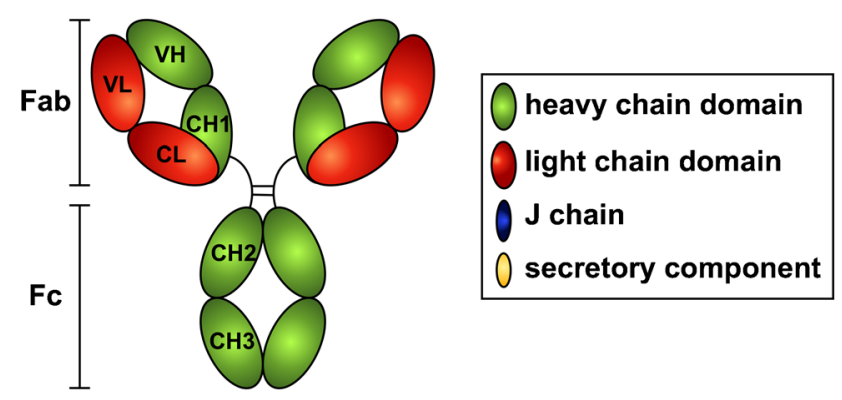

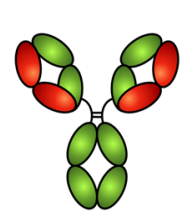

IgG1

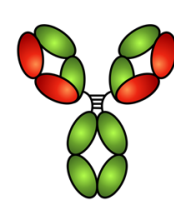

$\lg G 2$

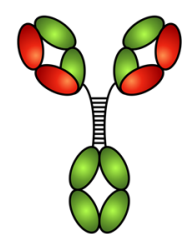

IgG3

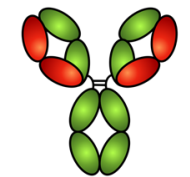

IgG4

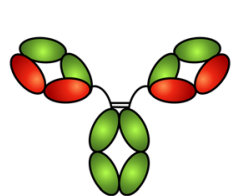

$\lg \mathrm{A} 1$

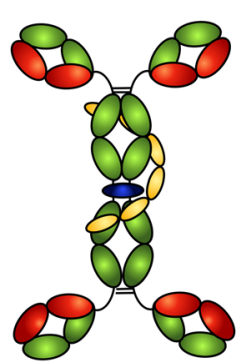

plgA

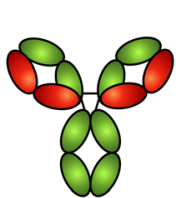

IgA2

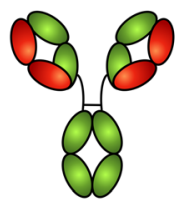

$\lg D$

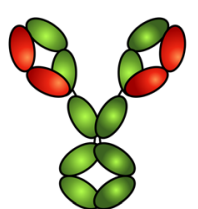

$\lg E$

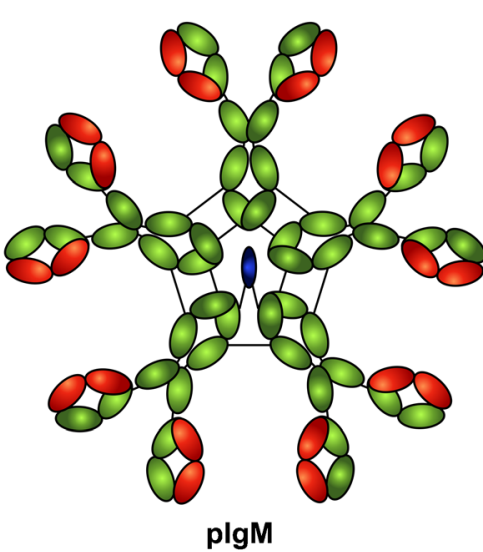

plgM

Fig. 1 Human Immunoglobulins. Schematic representation of the human immunoglobulin subclasses, monomeric IgG1, IgG2, IgG3, IgG4, IgA1, $\operatorname{IgA} 2, \operatorname{IgD}$, $\operatorname{IgE}$, and polymeric $(p) \operatorname{IgA}$ and $\operatorname{IgM}$ produced by $\mathrm{B}$ cells which develop in the bone marrow and express a membrane version of the antibody in the form of a B cell receptor or membrane immunoglobulin. Following activation by antigen in the periphery, specific $B$ cells undergo a series of processes that involve clonal proliferation, isotype switching (or class switch recombination), and affinity maturation, whereby somatic hypermutation of variable region genes leads to changes in the affinity of the BCR. B cells that bind to antigen with high affinity receive survival signals and may differentiate into memory B cells or plasma cells, the latter of which gives rise to secretion of high affinity antibodies. Long-lived, terminally differentiated plasma cells migrate to the bone marrow where they are thought to produce in excess of $10^{8}$ antibody molecules per hour [4]. Human antibodies are grouped into five classes (IgD, $\operatorname{IgM}$, IgA, $\operatorname{IgE}$, and IgG, Fig. 1) with $\operatorname{IgA}$ and $\mathrm{IgG}$ further divided into two and four subclasses (IgA1 and $\operatorname{IgA} 2, \operatorname{IgG} 1, \operatorname{IgG} 2, \operatorname{IgG} 3$, and IgG4), respectively, [5].

IgM is expressed as a monomer on the cell surface during $\mathrm{B}$ cell development. Following maturation, IgM is secreted by activated $\mathrm{B}$ cells as a pentamer or, less commonly as a hexamer, with the addition of the J-chain (Fig. 1). The multimeric structure of IgM increases avidity of antigen binding thus enhancing its functional activities including opsonization and complement fixation. IgM comprises around $10 \%$ of serum antibodies and is important for primary immune responses [6]. A significant proportion of IgM is of low affinity and often polyreactive; this latter property may be important for broad recognition of pathogens during primary responses. IgD is co-expressed with IgM on naïve B cells prior to isotype switching. Although $\operatorname{IgD}^{+} \mathrm{B}$ cells can differentiate into plasma cells, this monomeric antibody comprises less than $0.5 \%$ of serum. The immune function of secreted $\operatorname{IgD}$ is poorly defined; however, class-switched $\operatorname{IgM}^{-} \operatorname{IgD}^{+} \mathrm{B}$ cells resident in human respiratory mucosa are thought to play an important role in immunity to pathogens through direct interactions with basophils [7, 8]. IgG1 is the most well-studied and hence well-defined of the antibody subclasses owing to its abundance in serum, comprising around half of all serum antibodies. Like all IgG antibodies [9•], IgG1 is monomeric and is usually generated during secondary immune responses to protein antigens, mediating robust effector functions. IgG1 binds with high affinity to IgG receptors and efficiently triggers the complement cascade. $\operatorname{IgG} 2$, around $16 \%$ of serum antibodies, dominates the antibody response to carbohydrates such that nearly all antibodies specific for bacterial polysaccharides are IgG2 [10]. IgG3 is the most potent IgG subclass in terms of effector function, due to its exceptional ability to activate complement and bind to IgG receptors. Like IgG1, it is generated in response to protein antigens but is present at much lower concentrations, comprising just $5 \%$ of serum antibodies. IgG3 has an unusually long hinge consisting of 62 amino acids compared to IgG2, IgG4 (both 12 amino 
acids), and IgG1 (15 amino acids). IgG4 is the least abundant IgG subclass comprising just $3 \%$ of serum antibodies. It appears following long-term exposure to antigen and is generally regarded as an anti-inflammatory antibody, often associated with immune tolerance [11]. In addition, IgG4 is unable to fix complement and binds with lower affinity to IgG receptors than IgG1 [12•]. Conversely, the spectrum of conditions known as IgG4-related disease is characterized by high concentrations of serum IgG4 and inflammatory infiltration of $\mathrm{IgG} 4^{+}$plasma cells into tissue [13]. IgA1 and $\operatorname{IgA} 2$ are produced predominantly at mucosal surfaces where they are secreted in a dimeric form in combination with a J-chain and an additional polypeptide, the secretory component (Fig. 1) that protects the antibodies from proteolytic degradation. In serum, IgA exists as a monomer with IgA1 accounting for around $13 \%$ of serum antibodies and IgA2 $3 \%$. IgA2 is the predominant subclass in secretions and gut-associated lymphoid tissue whereas IgA1 is produced at higher proportions in secondary lymphoid tissue [14]. Secretory IgA1 and IgA2 are poor at activating inflammatory immune responses and are unable to fix complement but rather act to neutralize antigens through the process of immune exclusion. In contrast, serum IgA1 can initiate effective immune responses following binding to $\mathrm{Fc} \alpha \mathrm{RI}$ on the surface of granulocytes. IgE is the least abundant isotype in human serum comprising less than $0.01 \%$ of serum antibody in non-atopic individuals and may be up to ten times higher in allergic individuals, though still low relative to other isotypes. This low abundance is attributed to the potent pro-inflammatory immune responses elicited by $\operatorname{IgE}$ through interaction with its receptors FceRI and FceRII (CD23) expressed on the surface of granulocytes and antigen-presenting cells. IgE is well-known for its central role in allergic disease [15].

Since their first description by Paul Ehrlich over a century ago, our understanding of human antibodies has revealed the incredible diversity that these molecules possess. Human antibodies have broad effector functions that can act at every site of the human body, often with precise specificity for antigen targeting. As the basis of humoral immunity, antibodies provide protection against infectious disease, regulate immune responses, and maintain immune homeostasis. It is perhaps no surprise that we have realized the potential of antibodies for the benefits of human health.

\section{The Advent of Therapeutic Monoclonal Antibodies for Human Disease}

In 1984, Georges Köhler and Cesar Milstein were awarded the Nobel Prize for Medicine for their development of hybridoma technology nearly a decade previously [16]. This pioneering technique provided the tools for the generation of monoclonal antibodies, mAbs (i.e., antibodies of a single specificity) and ultimately for their diverse application in scientific research and in diagnostic and therapeutic medicine. Hybridoma technology involves the fusion of B cells from immunized mice with myeloma cells to produce an immortalized cell line capable of continuous production of mAbs specific for a desired target. Early clinical studies with hybridoma-derived mAbs found that therapeutic administration resulted in the development of immune responses directed towards the murine proteins. These responses caused either a failure of therapy due to the blocking or neutralizing effects of the anti-mAb, antiidiotypic response [17] or immediate or delayed hypersensitivity reactions. Efforts to overcome these adverse effects were developed during the 1980s following the advent of recombinant technology. One such approach involved the production of chimeric antibodies in which the murine constant regions were replaced with human constant regions using molecular cloning $[18,19]$. An added advantage of the incorporation of a human $\mathrm{Fc}$ was their ability to interact with human $\mathrm{Fc}$ receptors and complement components thereby facilitating cooperation with the immune system. Although this represented a significant improvement in terms of treatment efficacy, chimeric antibodies also elicit anti-idiotypic responses. Subsequently, humanized antibodies were developed in which the hypervariable loops (CDR) from murine antibodies were grafted onto human framework (FR) regions [20] resulting in a marked reduction in immunogenicity. The first $\mathrm{mAb}$ licensed for use in humans was muromonab, a murine $\operatorname{IgG} 2 \mathrm{a}$ antibody generated by hybridoma technology, which targets human CD3 to treat severe steroid-resistant transplant rejection [21]. Although effective, muromonab caused significant adverse effects due to (i) stimulation of potent $\mathrm{T}$ cell responses, (ii) the production of anti-mouse antibodies, reducing the efficacy of the treatment, and (iii) isolated cases of anaphylaxis. These ultimately led to its withdrawal from the market. Since then, $45 \mathrm{mAbs}$ have been approved for use in humans in the USA. A further four are currently under review and many more in clinical trials. The overwhelming majority of these are chimeric or humanized forms. Despite the success yielded by humanization of mAbs, this technically challenging approach often resulted in reduced affinity binding of the antibody to its target, the development of fully human antibodies was therefore considered an attractive alternative approach.

\section{The Development of Human Monoclonal Antibodies}

In 1985, following the development of transgenic mice, Alt and colleagues suggested that such technology could eventually be used to "engineer a mouse to make specific human antibodies," they wrote that "although conceptually outlandish, such genetic programming experiments may actually be realized in the not too distant future." [22] Their predictions were correct and less than a decade later the first publications 
described the generation of fully human mAbs from transgenic mice $[23,24]$. This approach involves replacing the entire antibody repertoire of the mouse with genes encoding human antibodies. Following immunization, standard hybridoma techniques can be employed to generate fully human monoclonal antibodies. Like traditional hybridomas, this technique is limited to immunogenic, non-toxic antigens but takes advantage of the in vivo affinity maturation process, resulting in highly specific antibodies.

Alongside the development of transgenic technology, phage display provided a novel complementary approach for the development of human monoclonal antibodies. Phage display was first described in 1985 [25] and later used to generate libraries encoding antibody genes [26]. Antibody repertoires from humans or immunized animals are generated by PCR amplification of the variable regions of heavy and light chain fragments. The PCR products are then cloned into a phage display vector, and DNA encoding a single antibody fragment is ligated into the PIII (minor) or PVIII (major) coat protein gene of a single filamentous bacteriophage (such as M13). The phage is then transduced in E. coli, allowing expression of the antibody fragment as a fusion protein attached to the capsid. In this way, up to $10^{8}$ different antibody fragments may be displayed in a phage "library." Antigen-specific antibody fragments are identified through the process of panning whereby target antigens are immobilized, allowing binding and enrichment of specific antibody fragments [27]. Importantly, the sequence of the variable regions can be determined thus providing a link between antibody genotype (i.e., sequence) and phenotype (i.e., specificity or affinity).

\section{Human B Cells as a Source of Monoclonal Antibodies}

Immortalization with Epstein-Barr virus was one of the first techniques to allow the generation of monoclonal antibodies directly from human B cells [28]. Although this method proved useful in a research setting, the low efficiency of transformation limited its use for antibody discovery. An improved method for EBV transformation was developed in the laboratory of Antonio Lanzavecchia, in which the addition of TLR9 agonists (such as $\mathrm{CpG}$ ) led to more efficient transformation of memory B cells [29].

Alternative approaches have since been developed to isolate memory B cells from peripheral blood and then isolate and clone the antibody variable regions using single-cell expression cloning [30]. By using labeled antigens, specific memory B cells can be directly isolated by flow cytometry to generate human monoclonal antibodies with desired specificities [31]. This method of single B cell cloning has resulted in the identification of numerous monoclonal antibodies specific for diverse targets including viruses [32, 33], parasites
[34], and allergens [35••, 36]. Adaptations to this method include high-throughput culture of single B cells isolated from blood [37], which allows pre-screening of secreted antibodies in culture supernatant, so that only cells with desired specificities are subject to cloning and recombinant expression.

The development of high-throughput sequencing technology provided a novel approach to mine antibody repertoires with unprecedented depth [38]. This involves amplification of the antibody variable region genes followed by highthroughput sequencing. Typically, peripheral blood is used as a source of $\mathrm{B}$ cells for sequencing but has also been applied to determine immunoglobulin repertoires in mucosal tissues [39]. Immunoglobulin repertoire analysis is useful for analyzing the ancestral relationships between related clones and for examining the diversity and selection of antibodies. Although this approach has potential for identifying dominant clones of a given isotype, the ability to sequence only the heavy or light chains independently meant that information on the natural pairing of the respective chains is lost. Recent approaches have been developed to overcome this limitation. Reddy et.al [40] took advantage of the expansion of bone marrow plasma cells following immunization or infection to identify and express the most abundant $\mathrm{V}_{\mathrm{H}}$ and $\mathrm{V}_{\mathrm{L}}$ genes within the immunoglobulin repertoire. This resulted in a higher efficiency of antigen-specific antibodies than could be obtained through random pairing. The use of PCR to physically link IgH and IgL sequences from individual cells provides another method of retaining the natural pairing of heavy and light chains [41••]. In this approach, messenger RNA (mRNA) molecules are captured in an emulsion inside which the entire $V_{H}$ and $V_{L}$ regions are amplified by PCR then pooled for sequencing. A similar approach using "cell-barcoding" has also been employed for paired $\mathrm{V}_{\mathrm{H}}: \mathrm{V}_{\mathrm{L}}$ repertoire analysis; here, unique molecular barcodes are incorporated by "template-switching" during reverse transcription of mRNA from single B cells. This novel method was used to clone and express monoclonal auto-antibodies from the peripheral blood of patients with rheumatoid arthritis [42••] and Staphylococcus aureus antibodies isolated from patients with $S$. aureus bacteremia [43•].

\section{Novel Approaches to Allergen Immunotherapy}

For over a century, allergen immunotherapy (AIT) has remained the only form of treatment that can modulate the underlying mechanisms of allergic disease. Currently, AIT is used to treat allergic rhinitis, allergic conjunctivitis, allergic asthma, and insect venom allergy. Both subcutaneous (SCIT) and sublingual (SLIT) forms of treatment are approved, though alternative routes (e.g., intralymphatic [44] and epicutaneous [45]) are under evaluation. In particular, over the last decade, the potential benefit of oral immunotherapy (OIT) for the treatment of food allergy has been assessed 
in a large number of clinical trials [46]. Although the efficacy of AIT is well-documented, it is regarded as an "underused" form of treatment for allergic diseases [47] in part due to the lack of standardized treatment regimens which results in variations in allergen preparations and differences in clinical practices from region to region. Several other novel approaches to improve the efficacy and safety of AIT have been evaluated, such as the use of recombinant allergens, including engineered modified "hypoallergens," the use of novel adjuvants to target allergenic proteins more precisely to immune modulatory pathways or co-treatment with other anti-allergic drugs [48].

The use of conventional SCIT alongside anti-IgE treatment has been assessed in a number of clinical trials. Omalizumab is a humanized monoclonal antibody directed against the $\mathrm{C} \varepsilon 3$ domain of the constant $(\mathrm{Fc})$ region of IgE (trade name Xolair, Novartis) [49]. It is administered intra-venously or subcutaneously and binds specifically to human IgE preventing interactions with the high-affinity receptor FceRI. Due to steric hindrance, omalizumab cannot bind to receptor-bound $\operatorname{IgE}$ and thus does not induce cross-linking of effector cells. Omalizumab has proven efficacy in moderate and severe allergic asthma, and in seasonal and perennial allergic rhinitis [50]. A single dose results in a decrease of serum $\operatorname{IgE}$ and consequently a downregulation of Fc\&RI expression on mast cells and basophils [51]. The use of anti-IgE treatment alongside AIT was proposed on the basis that it would reduce the significant risk of systemic anaphylaxis that is associated with AIT. Indeed, pre-treatment with anti-IgE has been shown to significantly reduce the incidence of adverse reactions, particularly during the updosing phase of treatment and results in a greater reduction in symptoms than AIT alone [52-56]. While large clinical trials of anti-IgE and AIT have thus far been restricted to studies of allergic asthma and allergic rhinitis, recent smaller studies combining anti-IgE with OIT provide promise for this approach in the treatment of IgE-mediated food allergies [57, 58••]. Omalizumab is unsuitable for a significant proportion of patients who have high levels of serum IgE. Recently, however, a novel human anti-IgE mAb was generated that may be suitable for such patients. MEDI4212 was produced by phage display and affinity matured using combinatorial mutagenesis of the CDR regions, generating an antibody with 100 -fold increased affinity for IgE compared to omalizumab [59•].

The combination of monoclonal antibody therapy with AIT has been explored with other targets of the allergic response. IL-4 is a prototypic T helper 2 (Th2) cytokine produced primarily by $\mathrm{CD} 4^{+} \mathrm{T}$ cells as well as by basophils. The importance of IL-4 in Th2-mediated inflammation and the induction of IgE class switching prompted the generation of monoclonal antibodies designed to neutralize IL-4. Like other mAbs-targeting single cytokines (e.g., anti-IL-5 and anti-IL13), the results of clinical trials were disappointing, with variable levels of efficacy as a standalone treatment [60]. More recently, the use of anti-IL-4 in combination with AIT for allergic rhinitis was assessed in a double-blind study of 37 patients with seasonal allergic rhinitis [61]. Despite an apparent reduction in the numbers of IL-4-producing cells in peripheral blood, the concomitant use of anti-IL-4 with AIT had no additional beneficial effects on the clinical response. The lack of efficacy of anti-IL-4, in contrast to the synergistic effects of anti-IgE in combination with AIT, may reflect the important role of the humoral response in both allergy and tolerance induction. The induction of blocking antibodies, particularly of the IgG4 subclass is an important mechanism in the efficacy of AIT. In fact, blocking antibody responses have proven therapeutic properties in patients with severe allergic disease.

\section{The Induction of Blocking Antibodies by AIT}

In 1937, Robert Cooke and Mary Loveless demonstrated that co-administration of serum from subjects who had received multiple subcutaneous injections of ragweed pollen over 312 months, could inhibit immediate allergic responses in the skin, elicited by intradermal injection of ragweed with allergic serum [62]. These early experiments demonstrated that "blocking antibodies" are able to inhibit the activity of IgE in an allergen-specific manner. In 1978, Maurice Lessof and colleagues took this concept a step further when they demonstrated that an infusion of gamma-globulin from "hyperimmune" beekeepers, with high levels of anti-phospholipase IgG protected against systemic anaphylaxis. Administration of "protective serum" to five subjects with bee venom allergy lowered the threshold dose required to induce systemic reactions by 1.5 to 5 times the amount that was previously required. [63].

Later, similar studies $[64,65]$ provide proof of concept that administration of allergen-specific blocking antibodies may represent a valid therapeutic approach for allergic disease, one that is more recently gaining favor following the advent of monoclonal antibody technology [66]. An important consideration for this approach is the polyclonal nature of $\operatorname{IgE}$ responses, which involve multiple epitopes often on several different allergenic proteins. Thus, a monoclonal antibody directed against a single allergenic epitope would be unlikely to provide a similar level of passive protection that can be achieved with hyperimmune serum. The use of multiple combinations of monoclonal antibodies is being evaluated for several human diseases [67]. In a murine model of allergic asthma, administration of a "polyclonal" mixture of seven recombinant ovalbumin (OVA)-specific IgG2b antibodies to OVAsensitized mice provided a better level of protection against OVA-induced airway inflammation and hyper-reactivity than a single monoclonal antibody [68]. 


\section{Role for Allergen-Specific Antibodies in Vaccine Design}

The availability of well-characterized allergen-specific antibodies could have broad applications for our understanding and treatment of allergic diseases, from direct therapeutic application as passive immunotherapy to the standardization of allergen extracts for AIT. In addition, allergen-specific monoclonal antibodies can facilitate the design of novel forms of allergen immunotherapy. Inhibiting the activity of $\operatorname{IgE}$ has clear benefits in terms of improving the safety and efficacy of AIT, exemplified by the concomitant use of anti-IgE. It follows that hypoallergens (i.e., allergens which lack IgE epitopes) would make excellent candidates for allergen immunotherapy. Early attempts to alter the allergenicity of immunotherapy vaccines through chemical modification (allergoids) had limited success due to lack of immunogenicity or residual IgE activity, but re-evaluation of this approach has led to a number of recent initiatives, most notably the EU-funded FAST project $[69 \bullet \bullet, 70]$.

Understanding the molecular determinants of IgE recognition would allow the rational design of recombinant hypoallergens for AIT. Epitopes formed by discreet continuous regions of polypeptide ("linear" epitopes) can be deduced by epitope arrays [71]. However, the majority of epitopes from both inhaled and food allergens are discontinuous or "conformational," formed by close association of amino acids in the three-dimensional structure. Such epitopes can only be defined by biophysical approaches such as X-ray crystallography or nuclear magnetic resonance (NMR). Of the known 827 allergens in the official WHO/IUIS database (www.allergen. org), protein database (PDB) structures are available for 92 $(11 \%)$ of these [72]. In turn, the structures of 11 allergenantibody complexes for six allergens (birch pollen, bee venom, cockroach, cow's milk, house dust mite, and grass pollen) have been solved [73-79] (Table 1). All of these complexes are formed of discontinuous epitopes, except for hyaluronidase from bee venom (Api $\mathrm{m} 2$ ) which comprises a continuous stretch of nine amino acids. However, the protruding loop structure formed by this region in the three-dimensional structure means that isolated peptides with an identical amino acid sequence are not recognized by the corresponding antibody or even by serum IgE [76]. Proof of principle for structure-based vaccine design is highlighted by studies on Bet $\mathrm{v} 1$, the major allergen from birch pollen. Based on X-ray crystallographic analysis of the murine Bet $\mathrm{v} 1$-specific mAb BV16 in complex with Bet v 1, Spangfort et.al. demonstrated that a single point mutation in the epitope of Bet $\mathrm{v}$ 1, abolishes binding of BV16 and reduces binding of serum $\operatorname{IgE}$ by $50 \%$ [80]. Thus, point mutations in IgE epitopes, guided by analysis of antibody allergen complex structures, can direct the design of hypoallergenic proteins for therapy of IgE-mediated allergy.

While the advent of component resolved diagnostics has revolutionized our understanding of patterns of sensitization, it has also highlighted the surprising disconnect between sensitization and reactivity and the considerable variation in $\operatorname{IgE}$ responses between individuals. The availability of allergenspecific antibodies directed against clinically relevant, allergenic epitopes would allow us to better understand the molecular determinants of allergenicity. Identification of dominant conformational epitopes through structural studies of antibody allergen complexes will ultimately lead to the engineering of recombinant hypoallergens for AIT.

\section{Conclusions}

The list of antibodies approved or in clinical trials is constantly evolving as this form of treatment is adopted in broad areas of medicine. With rapid improvements in antibody engineering, antibody expression, and greater understanding of antibody effector functions, we have entered an era of rapid progress. Antibodies can now be made smaller (e.g., diabodies [81]), more stable (e.g., through hinge engineering [82]), more specific (e.g., in vitro affinity maturation [83]) and ultimately more efficacious. Our understanding of antibody responses in disease has improved as a direct result of high-throughput methods for isolation and characterization of human antibodies and computational approaches to understand how antibody repertoires are shaped. Given the central role of antibody responses in allergic disease, we may now take advantage of these advances to improve our understanding of antibody
Table 1 Allergen-antibody complex structures

\begin{tabular}{llllll}
\hline Allergen & Source & mAb clone & Species & Isotype & Technology \\
\hline Gal d 4 & Hen's egg & HyHEL-10 & Mouse & IgG1 & Hybridoma \\
Bet v 1 & Birch pollen & BV16 & Mouse & IgG1 & Hybridoma \\
Bos d 5 & Cow's milk & D1 & Human & IgE & Phage display \\
Api m 2 & Bee venom & $21 \mathrm{E} 11$ & Mouse & IgG1 & Hybridoma \\
Bla g 2 & Cockroach & $7 \mathrm{C} 11$ & Mouse & IgG1 & Hybridoma \\
Phl p 2 & Grass pollen & HuMab2 & Human & IgE & Phage display \\
Der f 1/Der p 1 & House dust mite & $4 \mathrm{C} 1$ & Mouse & IgG1 & Hybridoma \\
\hline
\end{tabular}


allergen interactions and identify disease-relevant epitopes of clinically relevant allergens. The success of anti-IgE will hopefully encourage further work into the potential role of monoclonal antibodies for allergic disease. This form of treatment has the potential to speed up the progressively advancing progress that has thus far been made in improving the safety and efficacy of AIT.

\section{Compliance with Ethical Standards}

Conflict of Interest Dr. James declares no conflict of interest.

Human and Animal Rights and Informed Consent This article does not contain any studies with human or animal subjects performed by the author.

Open Access This article is distributed under the terms of the Creative Commons Attribution 4.0 International License (http:// creativecommons.org/licenses/by/4.0/), which permits unrestricted use, distribution, and reproduction in any medium, provided you give appropriate credit to the original author(s) and the source, provide a link to the Creative Commons license, and indicate if changes were made.

\section{References}

Papers of particular interest, published recently, have been highlighted as:

- Of importance

•• Of major importance

1. Noon L. Prophylactic inoculation against hay fever. Lancet. 1911;1: 1572.

2. Freeman J. Further observations on the treatment of hay fever by hypodermic inoculations of pollen vaccine. Lancet. 1911;2:814-7.

3. Calderón MA, Rodríguez Del Río P, Vidal C, Just J, Pfaar O, Linneberg A, et al. An EAACI "european survey on adverse systemic reactions in allergen immunotherapy (EASSI)": the methodology. Clin Transl Allergy. 2014;21:22.

4. Brieva JA, Roldán E, De la Sen ML, Rodriguez C. Human in vivoinduced spontaneous IgG-secreting cells from tonsil, blood and bone marrow exhibit different phenotype and functional level of maturation. Immunology. 1991;72:580-3.

5. Schroeder Jr HW, Cavacini L. Structure and function of immunoglobulins. J Allergy Clin Immunol. 2010;125:S41-52.

6. Boes M. Role of natural and immune IgM antibodies in immune responses. Mol Immunol. 2000;37:1141-9.

7. Chen $\mathrm{K}, \mathrm{Xu} \mathrm{W}$, Wilson $\mathrm{M}, \mathrm{He} \mathrm{B}$, Miller NW, Bengtén E, et al. Immunoglobulin $\mathrm{D}$ enhances immune surveillance by activating antimicrobial, proinflammatory and B cell-stimulating programs in basophils. Nat Immunol. 2009;10:889-98.

8. Chen K, Cerutti A. The function and regulation of immunoglobulin D. Curr Opin Immunol. 2011;23:345-52.

9. Vidarsson G, Dekkers G, Rispens T. IgG subclasses and allotypes: from structure to effector functions. Front Immunol. 2014;5:520. An up to date review of the IgG subclasses.

10. Barrett DJ, Ayoub EM. IgG2 subclass restriction of antibody to pneumococcal polysaccharides. Clin Exp Immunol. 1986;63:12734.
11. Aalberse RC, Stapel SO, Schuurman J, Rispens T. Immunoglobulin G4: an odd antibody. Clin Exp Allergy. 2009;39:469-77.

12. Davies AM, Sutton BJ. Human IgG4: a structural perspective. Immunol Rev. 2015;268:139-59. A comprehensive review on aspects of human IgG4 biology.

13. Deshpande V, Zen Y, Chan JK, Yi EE, Sato Y, Yoshino T, et al. Consensus statement on the pathology of IgG4-related disease. Mod Pathol. 2012;25:1181-92.

14. Gommerman JL, Rojas OL, Fritz JH. Re-thinking the functions of $\operatorname{IgA}(+)$ plasma cells. Gut Microbes. 2014;5:652-62.

15. Gould HJ, Sutton BJ. IgE in allergy and asthma today. Nat Rev Immunol. 2008;8:205-17.

16. Köhler G, Milstein C. Continuous cultures of fused cells secreting anti-body of predefined specificity. Nature. 1975;256:495.

17. Miller RA, Oseroff AR, Stratte PT, Levy R. Blood. 1983;5:988-95.

18. Morrison SL, Johnson MJ, Herzenberg LA, Oi VT. Chimeric human antibody molecules: mouse antigen-binding domains with human constant region domains. Proc Natl Acad Sci U S A. 1984;81: 6851-5.

19. Boulianne GL, Hozumi N, Shulman MJ. Production of functional chimaeric mouse/human antibody. Nature. 1984;312:643-6.

20. Jones PT, Dear PH, Foote J, Neuberger MS, Winter G. Replacing the complementarity-determining regions in a human antibody with those from a mouse. Nature. 1986;321:522-5.

21. Todd PA, Brogden RN. Muromonab CD3. A review of its pharmacology and therapeutic potential. Drugs. 1989;37:871-99.

22. Alt FW, Keith Blackwell T, Yancopoulos GD. Immunoglobulin genes in transgenic mice. Trends Genet. 1985;1:231-6.

23. Green LL, Hardy MC, Maynard-Currie CE, Tsuda H, Louie DM, Mendez MJ, et al. Antigen-specific human monoclonal antibodies from mice engineered with human Ig heavy and light chain YACs. Nat Genet. 1994;7:13-21.

24. Lonberg N, Taylor LD, Harding FA, Trounstine M, Higgins KM, Schramm SR, et al. Antigen-specific human antibodies from mice comprising four distinct genetic modifications. Nature. 1994;368: 856-9.

25. Smith GP. Filamentous fusion phage: novel expression vectors that display cloned antigens on the virion surface. Science. 1985;228: 1315-7.

26. McCafferty J, Griffiths AD, Winter G, Chiswell DJ. Phage antibodies: filamentous phage displaying antibody variable domains. Nature. 1990;348:552-4.

27. Lee CM, Iorno N, Sierro F, Christ D. Selection of human antibody fragments by phage display. Nat Protoc. 2007;2:3001-8.

28. Kozbor D, Roder JC. Requirements for the establishment of hightittered human monoclonal antibodies against tetanus toxoid using the Epstein-Barr virus technique. J Immunol. 1981;127:1275-80.

29. Traggiai E, Becker S, Subbarao K, Kolesnikova L, Uematsu Y, Gismondo MR, et al. An efficient method to make human monoclonal antibodies from memory B cells: potent neutralization of SARS coronavirus. Nat Med. 2004;10:871-5.

30. Tiller T, Meffre E, Yurasov S, Tsuiji M, Nussenzweig MC, Wardemann H. Efficient generation of monoclonal antibodies from single human B cells by single cell RT-PCR and expression vector cloning. J Immunol Methods. 2008;329:112-24.

31. Wrammert J, Smith K, Miller J, Langley WA, Kokko K, Larsen C, et al. Rapid cloning of high-affinity human monoclonal antibodies against influenza virus. Nature. 2008;453:667-71.

32. Di Niro R, Mesin L, Raki M, Zheng NY, Lund-Johansen F, Lundin $\mathrm{KE}$, et al. Rapid generation of rotavirus-specific human monoclonal antibodies from small-intestinal mucosa. J Immunol. 2010;185: 5377-83.

33. Wu X, Yang ZY, Li Y, Hogerkorp CM, Schief WR, Seaman MS, et al. Rational design of envelope identifies broadly neutralizing human monoclonal antibodies to HIV-1. Science. 2010;329:85661 . 
34. Maskus DJ, Bethke S, Seidel M, Kapelski S, Addai-Mensah O, Boes A, et al. Isolation, production and characterization of fully human monoclonal antibodies directed to Plasmodium falciparum MSP10. Malar J. 2015;14:276.

35.• Patil SU, Ogunniyi AO, Calatroni A, Tadigotla VR, Ruiter B, Ma A, et al. Peanut oral immunotherapy transiently expands circulating Ara h 2-specific B cells with a homologous repertoire in unrelated subjects. J Allergy Clin Immunol. 2015;136:125-34. In this study the authors used fluorescently-labeled antigen to isolate, clone and express a number of peanut-specific antibodies from peripheral blood.

36. James LK, Bowen H, Calvert RA, Dodev TS, Shamji MH, Beavil AJ, et al. Allergen specificity of IgG(4)-expressing B cells in patients with grass pollen allergy undergoing immunotherapy. J Allergy Clin Immunol. 2012;130:663-70.

37. Huang J, Doria-Rose NA, Longo NS, Laub L, Lin CL, Turk E, et al. Isolation of human monoclonal antibodies from peripheral blood B cells. Nat Protoc. 2013;8:1907-15.

38. Weinstein JA, Jiang N, White 3rd RA, Fisher DS, Quake SR. Highthroughput sequencing of the zebrafish antibody repertoire. Science. 2009;324:807-10.

39. Wu YC, James LK, Vander Heiden JA, Uduman M, Durham SR, Kleinstein SH, et al. Influence of seasonal exposure to grass pollen on local and peripheral blood $\operatorname{IgE}$ repertoires in patients with allergic rhinitis. J Allergy Clin Immunol. 2014;134:604-12.

40. Reddy ST, Ge X, Miklos AE, Hughes RA, Kang SH, Hoi KH, et al. Monoclonal antibodies isolated without screening by analyzing the variable-gene repertoire of plasma cells. Nat Biotechnol. 2010;28: 965-9.

41.• DeKosky BJ, Ippolito GC, Deschner RP, Lavinder JJ, Wine Y, Rawlings BM, et al. High-throughput sequencing of the paired human immunoglobulin heavy and light chain repertoire. Nat Biotechnol. 2013;31:166-9. In this study emulsion PCR was used to amplify naturally paired heavy and light chain sequences of single peripheral $B$ cells prior to high-throughput sequencing.

42.• Tan YC, Kongpachith S, Blum LK, Ju CH, Lahey LJ, Lu DR, et al. Barcode-enabled sequencing of plasmablast antibody repertoires in rheumatoid arthritis. Arthritis Rheum. 2014;66:2706-15. Using a novel DNA-barcoding method, the authors sequenced paired antibody repertoires from peripheral blood plasmablasts of rheumatoid arthritis patients. Based on these sequences, recombinant monoclonal antibodies were generated by molecular cloning and shown to bind to autoantigens implicated in disease pathogenesis.

43. Lu DR, Tan YC, Kongpachith S, Cai X, Stein EA, Lindstrom TM, et al. Identifying functional anti-Staphylococcus aureus antibodies by sequencing antibody repertoires of patient plasmablasts. Clin Immunol. 2014;152:77-89. In a validation of the DNAbarcoding approach described above, the authors isolated, cloned and characterized the functional activity of human Staphylococcus aureus-specific antibodies.

44. Senti G, Kündig TM. Intralymphatic immunotherapy. World Allergy Organ J. 2015;8:9.

45. Senti G, von Moos S, Tay F, Graf N, Johansen P, Kündig TM. Determinants of efficacy and safety in epicutaneous allergen immunotherapy: summary of three clinical trials. Allergy. 2015;70:70710 .

46. Le UH, Burks AW. Oral and sublingual immunotherapy for food allergy. World Allergy Organ J. 2014;7:35.

47. Jutel M, Agache I, Bonini S, Burks AW, Calderon M, Canonica W, et al. International consensus on allergy immunotherapy. J Allergy Clin Immunol. 2015;136:556-68.

48. Casale TB, Stokes JR. Immunotherapy: what lies beyond. J Allergy Clin Immunol. 2014;133:612-9.
49. Presta LG, Lahr SJ, Shields RL, Porter JP, Gorman CM, Fendly $\mathrm{BM}$, et al. Humanization of an antibody directed against IgE. J Immunol. 1993;151:2623-32.

50. Holgate ST, Djukanović R, Casale T, Bousquet J. Antiimmunoglobulin $\mathrm{E}$ treatment with omalizumab in allergic diseases: an update on anti-inflammatory activity and clinical efficacy. Clin Exp Allergy. 2005;35:408-16.

51. Chang TW. The pharmacological basis of anti-IgE therapy. Nat Biotechnol. 2000;18:157-62.

52. Massanari M, Nelson H, Casale T, Busse W, Kianifard F, Geba GP, et al. Effect of pretreatment with omalizumab on the tolerability of specific immunotherapy in allergic asthma. J Allergy Clin Immunol. 2010;125:383-9.

53. Casale TB, Busse WW, Kline JN, Ballas ZK, Moss MH, Townley $\mathrm{RG}$, et al. Omalizumab pretreatment decreases acute reactions after rush immunotherapy for ragweed-induced seasonal allergic rhinitis. J Allergy Clin Immunol. 2006;117:134-40.

54. Kuehr J, Brauburger J, Zielen S, Schauer U, Kamin W, Von Berg A, et al. Efficacy of combination treatment with anti-IgE plus specific immunotherapy in polysensitized children and adolescents with seasonal allergic rhinitis. J Allergy Clin Immunol. 2002;109:274 80.

55. Rolinck-Werninghaus C, Hamelmann E, Keil T, Kulig M, Koetz K, Gerstner B, et al. The co-seasonal application of anti-IgE after preseasonal specific immunotherapy decreases ocular and nasal symptom scores and rescue medication use in grass pollen allergic children. Allergy. 2004;59:973-9.

56. Kamin W, Kopp MV, Erdnuess F, Schauer U, Zielen S, Wahn U. Safety of anti-IgE treatment with omalizumab in children with seasonal allergic rhinitis undergoing specific immunotherapy simultaneously. Pediatr Allergy Immunol. 2010;21:160-5.

57. Nadeau K, Schneider L, Hoyte E, Borras I, Umetsu D. Rapid oral desensitization in combination with omalizumab therapy in patients with cow's milk allergy. J Allergy Clin Immunol. 2011;127:17224.

58.• Schneider LC, Rachid R, LeBovidge J, Blood E, Mittal M, Umetsu DT. A pilot study of omalizumab to facilitate rapid oral desensitization in high-risk peanut-allergic patients. J Allergy Clin Immunol. 2013;132:1368-74. Omalizumab was administered prior to and during oral peanut desensitization in children at high risk of severe allergic reactions. This pilot study provided evidence that omalizumab can facilitate oral immunotherapy for food allergy by reducing side effects in high risk patients.

59. Cohen ES, Dobson CL, Käck H, Wang B, Sims DA, Lloyd CO, et al. A novel IgE-neutralizing antibody for the treatment of severe uncontrolled asthma. MAbs. 2014;6:756-64. Using phage-display technology and antibody engineering, the authors describe a monoclonal anti-IgE with improved affinity binding to IgE.

60. Hilvering B, Pavord ID. What goes up must come down: biomarkers and novel biologicals in severe asthma. Clin Exp Allergy. 2015;45:1162-9.

61. Chaker AM, Shamji MH, Dumitru FA, Calderon MA, Scadding GW, Makatsori M, et al. Short-term subcutaneous grass pollen immunotherapy under the umbrella of anti-IL-4: a randomized controlled trial. J Allergy Clin Immunol. 2015.

62. Cooke RA, Loveless M, Stull A. Studies on immunity in a type of human allergy (hayfever): serological response of nonsensitive individuals to pollen injections. J Exp Med. 1937;66: 689-96.

63. Lessof MH, Sobokta AK, Lichtenstein LM. Effects of passive antibody in bee venom anaphylaxis. Johns Hopkins Med J. 1978;142: $1-7$.

64. Bousquet J, Fontez A, Aznar R, Robinet-Levy M, Michel FB. Combination of passive and active immunization in honeybee venom immunotherapy. J Allergy Clin Immunol. 1987;79:947-54. 
65. Muller UR, Morris T, Bischof M, Friedli H, Skarvil F. Combined active and passive immunotherapy in honeybee-sting allergy. $\mathrm{J}$ Allergy Clin Immunol. 1986;78:115-22.

66. Flicker S, Gadermaier E, Madritsch C, Valenta R. Passive immunization with allergen-specific antibodies. Curr Top Microbiol Immunol. 2011;352:141-59.

67. Wang XZ, Coljee VW, Maynard JA. Back to the future: recombinant polyclonal antibody therapeutics. Curr Opin Chem Eng. 2013;2:405-15.

68. Moerch U, Haahr Hansen M, Vest Hansen NJ, Rasmussen LK, Oleksiewicz MB, Frandsen TP, et al. Allergen-specific polyclonal antibodies reduce allergic disease in a mouse model of allergic asthma. Int Arch Allergy Immunol. 2006;140:261-9.

69.• Zuidmeer-Jongejan L, Fernandez-Rivas M, Poulsen LK, Neubauer A, Asturias J, Blom L, et al. FAST: towards safe and effective subcutaneous immunotherapy of persistent life-threatening food allergies. Clin Transl Allergy. 2012;2:5. A review of the FAST (food allergy specific immunotherapy) project which aims to develop safer hypoallergenic recombinant allergens for allergen immunotherapy. The study will evaluate and compare methods for the production of hypoallergens, namely chemical modification versus site-directed mutagenesis.

70. Zuidmeer-Jongejan L, Huber H, Swoboda I, Rigby N, Versteeg SA, Jensen BM, et al. Development of a hypoallergenic recombinant parvalbumin for first-in-man subcutaneous immunotherapy of fish allergy. Int Arch Allergy Immunol. 2015;166:41-51.

71. Shreffler WG, Beyer K, Chu TH, Burks AW, Sampson HA. Microarray immunoassay: association of clinical history, in vitro $\mathrm{IgE}$ function, and heterogeneity of allergenic peanut epitopes. J Allergy Clin Immunol. 2004;113:776-82.

72. Ivanciuc $\mathrm{O}$, Schein $\mathrm{CH}$, Braun W. SDAP: database and computational tools for allergenic proteins. Nucleic Acids Res. 2003;31: 359-62.

73. Padlan EA, Silverton EW, Sheriff S, Cohen GH, Smith-Gill SJ, Davies DR. Structure of an antibody-antigen complex: crystal structure of the HyHEL-10 Fab-lysozyme complex. Proc Natl Acad Sci U S A. 1989;86:5938-42.
74. Mirza O, Henriksen A, Ipsen H, Larsen JN, Wissenbach M, Spangfort MD, et al. Dominant epitopes and allergic cross-reactivity: complex formation between a Fab fragment of a monoclonal murine IgG antibody and the major allergen from birch pollen Bet $\mathrm{v}$ 1. J Immunol. 2000;165:331-8.

75. Niemi M, Jylhä S, Laukkanen ML, Söderlund H, MäkinenKiljunen S, Kallio JM, et al. Molecular interactions between a recombinant IgE antibody and the beta-lactoglobulin allergen. Structure. 2007;15:1413-21.

76. Padavattan S, Schirmer T, Schmidt M, Akdis C, Valenta R, Mittermann I, et al. Identification of a B-cell epitope of hyaluronidase, a major bee venom allergen, from its crystal structure in complex with a specific Fab. J Mol Biol. 2007;368:742-52.

77. Li M, Gustchina A, Alexandratos J, Wlodawer A, Wünschmann S, Kepley CL, et al. Crystal structure of a dimerized cockroach allergen Bla g 2 complexed with a monoclonal antibody. J Biol Chem. 2008;283:22806-14.

78. Padavattan S, Flicker S, Schirmer T, Madritsch C, Randow S, Reese $\mathrm{G}$, et al. High-affinity IgE recognition of a conformational epitope of the major respiratory allergen $\mathrm{Phl} \mathrm{p} 2$ as revealed by X-ray crystallography. J Immunol. 2009;182:2141-51.

79. Chruszcz M, Pomés A, Glesner J, Vailes LD, Osinski T, Porebski PJ, et al. Molecular determinants for antibody binding on group 1 house dust mite allergens. J Biol Chem. 2012;287:7388-98.

80. Spangfort MD, Mirza O, Ipsen H, Van Neerven RJ, Gajhede M, Larsen JN. Dominating IgE-binding epitope of Bet $\mathrm{v} 1$, the major allergen of birch pollen, characterized by X-ray crystallography and site-directed mutagenesis. J Immunol. 2003;171: 3084-90.

81. Holliger P, Hudson PJ. Engineered antibody fragments and the rise of single domains. Nat Biotechnol. 2005;23:1126-36.

82. Salfeld JG. Isotype selection in antibody engineering. Nat Biotechnol. 2007;25:1369-72.

83. Chowdhury PS, Pastan I. Improving antibody affinity by mimicking somatic hypermutation in vitro. Nat Biotechnol. 1999; 17:568-72. 